\title{
Enactment Of The National Credit Act And Its Implication On New And Improved Borrowers Rights In South Africa
}

Paul Green, Durban University of Technology, South Africa

Teshani Sewnunan, Durban University of Technology, South Africa

\begin{abstract}
The National Credit Act, 2005 (NCA) was introduced to create a more stable credit market and is applicable to all credit transactions. One of the main objectives of the Act is to establish new and improved rights for credit consumers. As a result, credit providers are obliged to comply with the NCA and enforce the new and improved rights. The purpose of this research paper is to determine if the NCA has established new and improved rights for home loan borrowers. The study utilised a mixed methods approach. Using a convenience sampling technique, a sample size of 250 respondents was used. The findings of the study revealed that borrowers' rights are being enforced by credit providers by maintaining confidentiality, providing information to home loan borrowers on a regular basis and, most importantly, ensuring that home loan borrowers are well informed prior to entering the home loan credit agreement.
\end{abstract}

Keywords: NCA; Credit Providers; Rights; Home Loan; Borrowers; Credit

\section{INTRODUCTION}

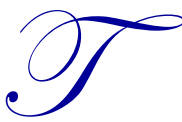

he South African financial sector has endured several transformations over the past two decades and this sentiment is also echoed by Peters (2009). The outcome of the apartheid system resulted in rigorously distorting the South African Financial Sector (RSA, 1994 RDP). Prior to 1994, the apartheid government employed many financial policies within the financial sector that resulted in inefficiencies and a major portion of the South African populace were restricted legal access to formal credit. As a consequence, the effect of these policies brought about restricted market competitiveness and was of benefit to only a minority of South Africans (Kirsten, 2006:2). Variable interest rates dominated the residential mortgage market and low income earners remained victims of home loan default, resulting from the lack of default literacy (Mkukwana, 2012:13).

The National Credit Act No. 34 of 2005 (NCA) was promulgated on the $1^{\text {st }}$ June 2007 to bring about stability within the credit market and is applicable to all types credit transactions. There are many objectives stipulated within the Act however, one of the key objectives of the Act is to establish new and improved rights for credit consumers. According to Van Heerden (2008:28), the NCA is a unique piece of legislation in that it is represented as a legally binding document, allowing for all credit transactions to be administered and regulated by a single Act. The NCA was introduced to protect consumers and principally address consumer credit problems. The Act benefited consumers by providing the necessary knowledge to assist consumers in managing their debt and understanding the consequences of payment defaults, prior to entering into a credit agreement. In addition to the benefits, the Act makes certain that all related transactions are transparent, fair and simple to understand and provides the consumer the right to enquire and obtain further clarity of information as required (Pillay, 2009: 2). The NCA further protects consumers from exploitation by financial institutions and prevents consumers from getting into credit agreements that are not in their best interests. It intends to ensure that credit providers do not take 
advantage of consumers through their status of over indebtedness and reckless lending, and provides additional clarity on payment defaults on consumer accounts and the basis of default collection (Rossouw, 2008:2).

\section{LITERATURE REVIEW}

In 2012, the National Credit Regulator conducted a review on the impact of the National Credit Act on South Africa's credit market. The review report indicated that the implementation of the NCA has undoubtedly stabilized the South African economy during the year of the credit crisis in 2008 and will continue to do for years to come. Consumer over-indebtedness had decreased significantly since the NCA was introduced. With regards to reckless lending, the NCA helps prevent consumers from getting into much credit and cautions the credit provider from entering into reckless lending agreements by providing sanctions for credit providers. According to Stoop and Louw (2011:2) credit providers should refrain from engaging into a credit contract without properly assessing the consumer's understanding of the risks and the cost of the proposed credit and his rights and obligations under the proposed agreement. Credit providers are further advised to disclose all relevant information to credit consumers and enforce the new and improved consumer rights set out by the NCA.

Dippenaar (2013:1) reported on the practical impact of the NCA, arguing that credit providers will need to strengthen lending criteria; especially with large loans and that the duty of the credit provider is to ensure that consumers understand the costs, risks, obligations and rights under the credit agreement. Credit providers are required to conduct a thorough investigation of the consumer's credit history prior to approving the credit and to safeguard against reckless lending. The NCA, has triggered numerous alterations in various sectors within the credit market.

Despite the numerous research projects undertaken to investigate the impact on the NCA, no research has been conducted to investigate if the NCA has established new and improved rights for credit providers.

\section{The National Credit Act No.34 of 2005}

Prior to the enactment of the NCA, the credit industry was controlled by the Usury Acts and their Exemption Notices. The NCA was the government's effort to keep the credit market regulated. However, due to rapid changes overtime in the market, there has been a constant need to review and amend credit legislation. Prior to $1^{\text {st }}$ June 2007, the Usury Act No. 73 of 1968 and the Credit Agreements Act No. 75 of 1980, had been the cornerstones of consumer credit in South Africa. These two Acts were, however, inconsistent with each other which undermined the regulation of consumer credit. In the period prior to the introduction of the NCA, obtaining credit was relatively easy as the credit applicants were not subjected to in-depth scrutiny (Mlandu, 2007:16). Consequently, finance providers advanced substantial amounts to applicants, many of whom could not repay their liabilities as they fell due. To remain profitable, the finance providers hiked the overall cost of borrowing through high interest rates, service and initiation fees as there was no limit to the interest rates or fees that registered finance providers could lawfully charge (Campbell, 2006:62). In addition, the finance providers masked the true cost of credit. It was then that the government intervened by enacting the National Credit Act No. 34 of 2005 (NCA) which came into effect on $1^{\text {st }}$ of June 2007.

The NCA was introduced with the following objectives (Rossouw, 2008:29):

- To provide one set of rules for all credit activities;

- $\quad$ To prevent reckless lending;

- To prevent over-indebtedness;

- $\quad$ To prevent unfavourable lending practices to credit consumers; and

- To establish new and improved rights for credit consumers.

The NCA has introduced many objectives; however this research paper focuses on determining if the NCA has established new and improved rights for credit consumers. 


\section{Additional Consumer Benefits: Establishment of New and Improved Rights for Home Loan Borrowers}

Before the implementation of the NCA, the cost of credit was exceptionally high with interest rates on onemonth loans up to 30\% per month, and the average interest on micro loans under the Exemption Notice close to $90 \%$ a year (Davel, 2007). The credit provider's disclosure of credit was misleading and customers often did not understand the full cost of credit. The NCA intends to eliminate the unfavourable lending practices. To achieve this objective, the Act requires that an advertisement for credit must show the instalment amount, the number of instalments, the total amount of all the instalments, including the interest fees and compulsory insurance, the interest rate, and any residuals in a font size not smaller than the average font size of the advert (Davel, 2007). This is meant to ensure that the credit consumer is fully aware of what the cost of goods will be after it has been fully paid off including all the optional items.

The NCA seeks to provide additional benefits for credit consumers. However, prior to the enactment of the NCA, approximately $70 \%$ of South Africans relied on money lenders and they were not adequately protected by legislation. Firstly, the credit access processes were not user friendly and thus were not understood by the majority of mostly illiterate populace (Shelembe, 2006:2; Kotze and Smit, 2008). Secondly, many consumers were subjected to misleading advertisements often concealing the true cost of credit and were unaware of their credit status as well as their consumer rights (Van Heerden, 2008:30). Therefore, the NCA was introduced to protect the rights of consumers. One of the benefits of the NCA is the new improved banking consumer rights (The banking association South Africa, 2014).

Before the NCA, these rights were very limited and banks were not obligated to provide reasons for their decisions or explanations to consumers. The NCA affords the credit consumer with the following rights, among others:

- $\quad$ The right to apply for credit;

- $\quad$ The right to know why credit was refused;

- The right to receive information in an official language;

- The right to information in a plain and understandable language;

- $\quad$ The right to receive documents; and

- The right to confidentiality.

The Act also intends to provide a tranquil credit market by bringing along with it the National Credit Regulator, a regulatory body responsible for, inter alia, developing an accessible credit market and the Consumer Tribunal responsible for hearing cases on non-compliance with the Act. For the first time, South Africa has a single Credit Act to address all credit problems. Whether the Act has had a positive or negative impact on the South African Financial Sector is yet to be determined. It is clear that the NCA aims at preventing reckless lending, shielding borrowers from becoming over indebted and protecting the consumer from malpractices of the credit provider. The NCA brings along with it the National Credit Regulator and the Consumer Tribunal that are responsible for overseeing the credit market and providing support to help ensure the aims within the NCA are being met.

\section{RESEARCH METHODOLOGY}

\section{Research Design}

A mixed methods approach was utilized for the study. The use of this approach contributes largely to strengthening the research study by providing a greater understanding of the research problem (Creswell, 2009:11). According to Myers (2009:8) one benefit of using this research method is that it enables the researcher to understand, interpret and view the context in which decisions and actions occur. Qualitative and quantitative research was conducted by administering questionnaires to home loan borrowers in the Pinetown area. 


\section{Population and Sample}

Research was conducted specifically in the Pinetown area and focused on registered home loan borrowers. The registered home loan borrowers had to have obtained a home loan (mortgage bond) registered in their names between 2009 - 2013. A selected sample size of 250 home loan borrowers participated in the study and a convenience sampling technique was employed. A questionnaire was administered to the participants. The researcher surveyed 190 home loan borrowers as part of the sample population for data collection. The study received a $76 \%$ response rate.

\section{Data Collection}

Primary data was collected by means of administering questionnaires to registered home loan borrowers in the Pinetown area. Primary data is referred to as data in its original form and can be collected through questionnaires (Kothari, 2004:95). Research was conducted at the Knowles Spar in Pinetown for a period of three weekends. Respondents were approached to participate in the research study. Clear explanations were provided to respondents regarding the aims and purpose of the study. Participants were advised to answer the questionnaire truthfully and without any fear of intimidation as confidentiality and anonymity will be maintained at all times. The questionnaire was sub-divided into various sections and comprised of open-ended, close-ended questions and a Likert scale. The various sections within the questionnaire intended to assess if the NCA has established new and improved rights for home loan borrowers.

\section{Validity and Reliability}

Applying a mixed methods approach, both qualitative and quantitative methods were employed to gather accurate reliable information assessing if the NCA has established new and improved rights for home loan borrowers. Utilizing mixed methods research increases validity by including various methods of inquiry and numerous traits in a research design (De Vos, Strydom, Fouché and Delport, 2011:434). The results of a multimethod study can only be termed credible and relied upon if the data collected is valid, reliable and analysed appropriately (Wagner, Kawulich and Garner, 2012:80). To enhance validity, the researcher administered questionnaires to random individuals that represented the sample of the target population. The reliability and validity statistics are illustrated below.

The two most important aspects of precision are validity and reliability. Reliability is computed by taking several measurements on the same subjects. A reliability coefficient of 0.70 or higher is considered as "acceptable" (Nunnally, 1978).

Table 1 reflects the Cronbach's alpha score for all of the ordinal items that constituted the questionnaire

Table 1. Cronbach's alpha validity score

\begin{tabular}{c|c|c|cc}
\hline \multicolumn{3}{c}{ Case Processing Summary } & N \\
\hline \multirow{3}{*}{ Cases } & & N & 91.6 \\
& Valid & 174 & 8.4 & 100.0 \\
\hline
\end{tabular}

Table 1 indicates the validity score of $91.6 \%$ obtained and Table 2 illustrates the reliability score for the proposed study.

Table 2. Cronbach's alpha reliability score

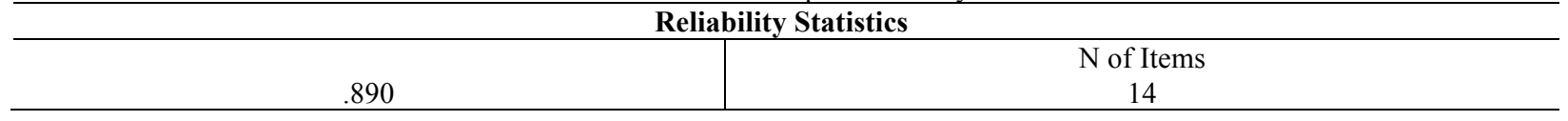

The overall reliability score of 0.890 satisfies the minimum recommended value of 0.70 . This indicates a high (overall) degree of acceptable, consistent scoring for this research. 


\section{FINDINGS}

The research objective explored the following areas: assessing respondents' knowledge of the NCA; enquiry of knowledge and understanding of consumer rights; and if these rights are being enforced by credit providers. In other words, did credit providers provide suitable explanations to borrowers on all aspects relating to their home loan? These areas of enquiry are illustrated in figure1.

Figure 1. Knowledge of the NCA and Home Loan Borrowers' Rights

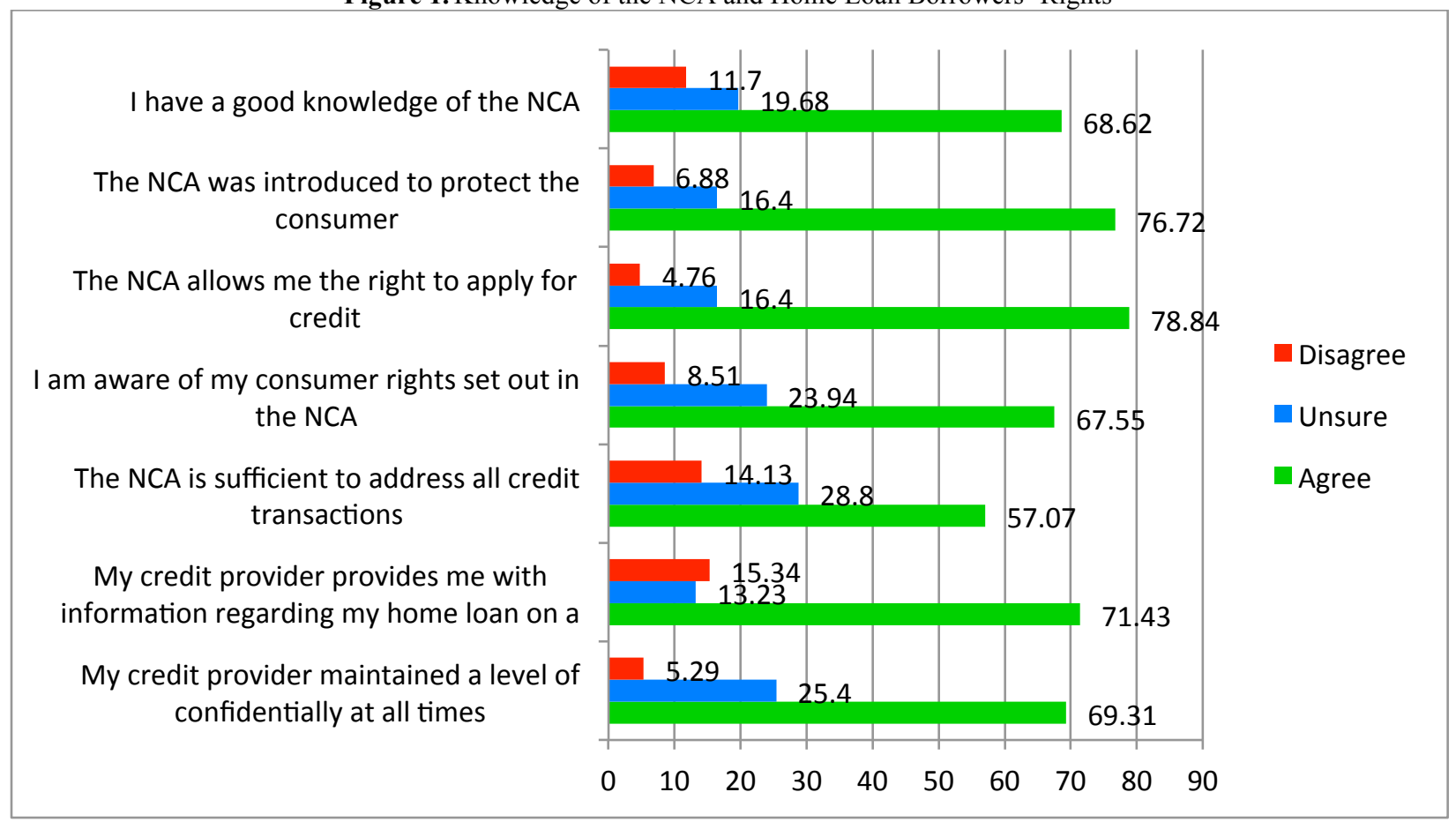

In figure 1 the majority of respondents (70\%) indicated that they were in agreement and $11 \%$ disagreed to having good knowledge of the NCA. This indicates that, despite a large percentage of respondents having a good knowledge of the NCA, there seem to be some individuals that do not have basic knowledge of the NCA and are unaware of the content of the NCA.

According to Pillay (2009:2), the NCA was enacted for the protection of consumers and to address consumer credit problems. It is interesting to note that respondents revealed a $(76 \%)$ agreement that the NCA was introduced to protect the consumer. A further $16 \%$ of respondents indicate a level of unsure and $6 \%$ disagreed. Therefore, there appears to be a significant link of $70 \%$ agreement between having good knowledge of the NCA and the (76\%) agreed that the NCA was introduced to protect the consumer. These findings provide clear indication that those with good knowledge of the NCA understand its purpose and aims in relation to protecting the consumer. Rossouw (2008:2) added that the Act protects consumers from exploitation by credit providers and curbs predatory lending by safeguarding consumers from lending malpractices by financial institutions, thereby protecting consumers from unfavourable lending practices.

It is noted that nearly $80 \%$ of the respondents agreed that the NCA allows consumers the right to apply for credit, while (4.76\%) disagreed and (16\%) were unsure. Van Heerden (2008:30) indicated that the NCA introduces new consumer rights, which allow consumers the right to apply for credit. One of the purposes stipulated in the National Credit Act, 2005, is to create an accessible consumer credit market (RSA, 2005, NCA No. 34). Nearly 70\% of respondents acknowledged that they are aware of their consumer rights set out in the NCA, with $24 \%$ unsure and $9 \%$ disagreed. This denotes that most consumers are aware of their consumer rights and that rights stipulated within the NCA are for the benefit of the credit consumer in the long-term. 
Just more than half the respondents (57\%) indicated their agreement that the NCA is sufficient to address all credit transactions, while $28 \%$ were unsure and $14 \%$ disagreed. Despite the low agreement response, all credit transactions are controlled and governed by the NCA (Van Heerden, 2008:28). This suggests that, despite the NCA regulating the credit industry for just over half a decade, a substantial proportion of credit consumers are still doubtful that the NCA is sufficient to address all credit transactions.

This raises many questions about the credit consumers' confidence in the South African credit market and also creates a level of uncertainty relating to the efficiency and effectiveness of the NCA.

A considerable portion (71\%) of total respondents indicated that credit providers do provide borrowers with information regarding their home loans on a regular basis, with $15 \%$ disagreeing and $13 \%$ unsure. Approximately $70 \%$ of home loan borrowers confirmed that credit providers did maintain a level of confidentiality, whilst $25 \%$ were unsure and $5 \%$ disagreed. These statements relate to consumer rights and indicate that the majority of respondents $(70 \%)$ have indicated that credit providers are considering their consumer rights and that information is received timeously and that their right to confidentiality was maintained.

However, there is still a significant portion of respondents that have indicated their level of uncertainty regarding their consumer rights. According to Van Heerden (2008:30), the NCA protects and benefits consumers. Credit consumers can enjoy their consumer rights established by the NCA. The NCA, 2005, allows consumers the right to receive information and the right to confidentiality. This means that credit providers are forced to comply with the Act and provide information to home loan borrowers whilst maintaining a level of confidentiality, which enforces home loan borrowers' rights and also ensures that borrowers are well informed prior to entering into a home loan credit agreement.

Table 3. Responses to Explanations Provided by Credit Providers

\begin{tabular}{l|c}
\hline & Percent \\
\hline The process of acquiring a home loan & 88.4 \\
\hline The method of determining your affordability & 80.4 \\
\hline How much is within your affordability bracket & 87.4 \\
\hline Preferred period ( 20years /30 years) over which you would take your home loan & 84.1 \\
\hline How much deposit was required Eg... (10\% of price of property ) & 76.3 \\
\hline Your monthly instalment amount payable & 92.6 \\
\hline The consequence of payment default & 78.4 \\
\hline The total cost of your home loan over your preferred period & 78.3 \\
\hline The additional monthly cost payable towards your bond cover (home loan insurance) & 78.4 \\
\hline Additional once of cost payable Eg... administration fees, legal costs, transfer duty & 86.8 \\
\hline Any other terms and conditions in compliance with acquiring a home loan & 68.0 \\
\hline
\end{tabular}

Table 3 shows that home loan borrowers were well informed by credit providers. However, not all information was appropriately explained to them. A large portion of respondents confirmed that the process of acquiring a home loan (88\%) and the method of determining their affordability (80\%) were explained to them. However, qualitative data revealed that a small portion of respondents added that they had conducted information searches on their own to gain additional knowledge on the process of acquiring a home loan and also to understand and know how much is within their affordability range. This indicates that the respondents that conducted information searches were more cautious about entering into a home loan agreement with credit providers over a long period. The information search may have assisted home loan borrowers in determining the various stages and requirements within the home loan process, but, most importantly, potential home loan borrowers would be aware as to how much is within their home loan affordability.

Sundgren (2003:9) explains that banks offer home loans to borrowers over a period of nearly 30 years and the purchased property is used as collateral for the loan. The majority of respondents $84 \%$ agreed that credit providers explained the preferred period of years over which the home loan is taken. However, a small portion of respondents explained that for their home loan, the credit provider did not explain to them the option of preferred number of years but instead they were just given 30 years by the credit providers. This is normally the maximum period over which a home loan can be taken. Most credit providers provide home loan borrowers with various 
options regarding the preferred years of their home loan, though; in this case, respondents were just given the maximum period of 30 years. This suggests that some credit providers are not providing proper explanations and information to home loan borrowers regarding the preferred period for their home loan. Consequently, home loan borrowers are being disadvantaged by paying more interest over the maximum period of 30 years.

Approximately $76 \%$ of home loan borrowers were informed of the amount of deposit required. Some respondents confirmed they were granted a $100 \%$ bond whilst others confirmed they had paid a $20 \%$ deposit. A total of $92 \%$ of the respondents received explanations about monthly repayments. Most respondents (78\%) confirmed that they received explanations for consequences of payment default and $78 \%$ of respondents agreed that additional monthly payments (bond insurances) were explained to them. Some respondents however, only found out about the cost of their monthly home loan installment when they had received their monthly statements. From table 3., there is a minority percentage of respondents that indicated for each statement that there was a problem and that explanations were at least inadequate. For instance, it is possible that some home loan borrowers did not understand the explanations.

The lack of explanations can mislead the home loan borrower, resulting in an increase in home loan default. It is important that consumers are informed about the consequences to payment default. Hui (2012:5) explains that payment default occurs when a home loan goes into negative equity and when repayments cannot be met. According to Sundgren (2003:9), where borrowers default on home loan repayments, the credit provider has a right to take legal possession and sell the property to pay the outstanding amounts owing. Payment default gives rise to mortgage credit risk, which occurs when a borrower becomes incapable of making repayments on his home loan (Otsman, 2010).

\section{CONCLUSION}

The majority of respondents were in agreement with many of the statements indicating that they have a good knowledge of the NCA and that they do know and understand their rights as established by the NCA. The findings revealed that credit providers did provide sufficient information to home loan borrowers as they were appropriately informed on all aspects that related to their home loans. This suggests that the enactment of the NCA has established new improved rights for home loan borrowers and that the rights are being enforced by credit providers by maintaining confidentiality, providing information to home loan borrowers on a regular basis and, most importantly, ensuring that home loan borrowers are well informed prior to entering the home loan credit agreement. However, despite the high agreement response for most statements, there is still a small portion of respondents who did not receive clear explanations for some statements above. A small percentage of respondents did indicate that they had conducted information searches on the process of acquiring a home loan. These respondents were noted for being cautious, before entering into a home loan credit agreement with credit providers.

An overall analysis revealed that the majority of respondents in Pinetown acknowledged they have good awareness of their consumer rights stipulated in the NCA. These rights: a) the right to apply for credit; b) the right to know why credit was refused; c) the right to receive information in an official and understandable language; d) the right to receive documents; and e) the right to confidentiality. Most Respondents also indicated that credit providers provided adequate explanations to them regarding all aspects of their home loans and that they were well informed. Drawing on the findings, in this instance, home loan borrowers are enjoying the benefits of the new improved rights for home loan borrowers established by the NCA and enforced by credit providers.

\section{RECOMMENDATIONS}

- Credit consumers should ensure that they are well informed prior to signing home loan credit agreements and repayments should be made timeously, as this will initiate a good credit record allowing the consumer better accessibility to credit in the future. This will help to develop and improve consumer rights and will be of benefit to consumers in the long-term.

- Credit providers should ensure all information is appropriately disclosed to home loans borrowers prior to approving and granting home loans. The consequence of non - disclosure of relevant information could misinform home loan borrowers and give rise to home default. 


\section{AUTHOR INFORMATION}

Dr Paul Green is a Senior Lecturer in the Department of Finance \& Information Management at the Durban University of Technology. He has a PhD from the University of KwaZulu-Natal. He has published in peer-reviewed journals and presented numerous papers at international conferences. E-mail: paulg@,dut.ac.za

Mrs Teshani Sewnunan has a Master of Technology Degree: Cost \& Management Accounting and lectures in the Department of Finance \& Information Management at the Durban University of Technology.

Email: Tishs@dut.ac.za

\section{REFERENCES}

Campbell, J. 2006. The cost of Credit in the micro-finance industry in South Africa. Unpublished Masters thesis. Rhodes University. South Africa.

Creswell, J. W. 2009. Research design: Qualitative, Quantitative and Mixed Methods Approaches. $3^{\text {rd }}$ ed. Los Angeles, California: Sage Publications.

Davel, G. 2007. Act Protects Consumers from Reckless Lending. Available online.

http://www.engineeringnews.co.za/print-version/act-protects-consumers-from-reckless-lending-2007-0928[Accessed: 2010, August 22].

De Vos, A. S., Strydom, H., Fouché, C. B. and Delport, C. S. L. 2011. Research of Grass Roots: For social sciences and human serve profession. $4^{\text {th }}$ ed. Pretoria: Van Schaik.

Dippenaar, A. 2013. The Practical Impact of The National Credit Act. Available online. https://www.compuscan.co.za/practical-impact-national-credit-act/ [Accessed: 2014, June 14].

Floyd, F. and Fowler, J. R. 2014. Survey Research Methods. Los Angeles, California: Sage.

Hui, W. 2012. An Investigation of Strategic Behaviour in Consumer Default. Unpublished Doctoral Thesis. The Ohio State University. United States.

Kirsten, M. 2006. Policy initiatives to expand financial outreach in South Africa. Session VII Notes. Development Bank of South Africa. Johannesburg. Available online. http://info.worldbank.org/etools/docs/library [Accessed: 2012, August 10].

Kothari, C. R. 2004. Research Methodology: methods and techniques. $2^{\text {nd }}$ rev. ed. New Delhi: New Age International Limited Publishers.

Kotze, L. and Smit, A. 2008. Personal Finances: what is the possible impact on entrepreneurial activity in South Africa. South African Business Review, 12(3): 156-172.

Mkukwana, K. 2012. The Impact of the Macroeconomic Factors on the Risk of Default: the Case of Residential Mortgages. Unpublished Masters Thesis. University of Witwatersrand, South Africa.

Mlandu, N. 2007. The Effectiveness of The National Credit Act (2005) in Curbing Consumer Indebtedness. Unpublished Masters Thesis. University of Pretoria. South Africa.

Myers, M. D. 2009. Qualitative Research in Business and Management. Los Angeles: Sage Publications.

Nunnally, J. C. 1978. Psychometric Theory. $2^{\text {nd }}$ ed. New York: McGraw-Hill.

Otsman. F. 2010. A Residential mortgage market in Crisis: Something to learn from a Swedish Case. Business and Economic History On-Line, 8: 1-12.

Peters, R. M. 2009. SMME Development Initiatives and its Constraints to Growth in South Africa. Unpublished Doctoral Thesis. University of Johannesburg. South Africa.

Pillay, S. 2009. The Paradoxical Effect of the National Credit Act on the Residential Property market in South Africa. Unpublished Masters Thesis. University of KwaZulu- Natal. South Africa.

Rossouw, Z. 2008. The Impact of The National Credit Act on Micro Lending Sales in a Bank in South Africa. Unpublished Masters Thesis. University of Pretoria. South Africa.

RSA. 2005. National Credit Act No. 34 of 2005. Cape Town: Government Printer.

RSA, 1994. The Reconstruction and Development Programme (RDP). A Policy Framework, Cape Town: Government Printer.

Shelembe, S. D. 2006. Barriers Preventing Marginal Income Group from Accessing Finance. Unpublished Masters Thesis. Durban University of Technology. South Africa.

Stoop, P.N. and Louw, M. K. 2011. The National Credit Act Regarding Suretyships 
and Reckless Lending. Potchefstroom Electronic Law Journal, 14(2): 66-96.

Sundgren, H. 2003. Global Urbanization Trends, Mega Cities and Development of Informal Settlements: A Case Study of the "Illegal" Housing Market in Fevela Rio das Pedras, Rio de Janeiro. Unpublished Masters Thesis. Royal Institute of Technology. Sweden.

The banking association South Africa. 2014. What are the Consumer Rights in Terms of the National Credit Act? Available online. http://www.banking.org.za/index.php/consumer-centre/national-credit-act [Accessed on: 2014, August 3].

The National Credit Regulator. 2012 - 2013. Annual Report. DTI, South Africa. The nct.org. About the National Consumer Tribunal. Available online. http://www.thenct.org.za/ [Accessed: 2011, February 18].

Van Heerden, G. 2008. The Potential Effect of The National Credit Act 2006 on the Future of Selected, Specialized Micro-Lending Institution in South Africa. Unpublished Masters Thesis. University of Pretoria, South Africa.

Wagner, C.,Kawulich, B. and Garner, M. 2012. Doing Social Research: A global context. Berkshire: McGraw-Hill Higher Education. 


\section{NOTES}

